\title{
OBJETO DE LEITURA: O MEME DA INTER NET COMO OPERACIONALIZADOR DE INTERPRETAÇÃO
}

\author{
Thiago Barbosa Soares \\ Doutor em Linguística pela Universidade Federal de São Carlos (UFSCar) \\ Professor Adjunto da Universidade Federal do Tocantins (UFT) / Campus Porto Nacional \\ thiagobsoares@bol.com.br
}

Sóstenes de Jesus Carvalho Santos

Mestre em Letras (Linguagens e Letramentos) pela Universidade Federal de Campina Grande (UFCG/PB) Professor do Instituto Federal de Educação, Ciência e Tecnologia de Mato Grosso do Sul (IFMS) / Campus de

Aquidauana

sostenes.santos@ifms.edu.br

\begin{abstract}
RESUMO
Este artigo analisa o gênero textual discursivo meme da internet como objeto de leitura e interpretação face à situações didáticas de aprendizagem, diante das quais o posicionamento do(a) leitor(a) tem de se direcionar crítica e analiticamente ao texto e ao mundo social e linguístico, visando à construção e (re)elaboração dos sentidos. Os autores que nos embasam neste itinerário são os seguintes: Freire (2011), Benveniste (2014), Chartier (1999), Soares (2004), Dawkins (2007), Bakhtin (2011), Adam \& Heidmann (2011), Marchuschi (2002), Brait (2000), Schneuwly \& Dolz (2004), Bawarshi \& Reiff, (2013), Kleiman (2005). Num primeiro momento, relacionamos indagações reflexivas acerca das dimensões composicional, linguística, discursiva e social dos chamados gêneros textuais discursivos, a fim de demarcar a necessidade de apropriação desses organismos materiais da linguagem como objetos e também como objetivos de uma prática didático-pedagógica em língua portuguesa. Num segundo momento, trazemos à baila, para efeito de elucidação apreciativa, o gênero meme propriamente dito, em exemplos retirados da internet, suporte/meio no qual eles circulam diariamente, atravessando as inúmeras redes sociais e sob os olhares dos incontáveis leitores que deles se valem em manuseios interativos os mais diversos. Em conclusão, temos que a leitura do meme como gênero que operacionaliza interpretações críticas do texto e do mundo perfaz uma pré-construção textual-discursiva de retomadas.
\end{abstract}

Palavras-chave: leitura, gêneros textuais discursivos, meme(s) da internet, ensino.

\begin{abstract}
This article analyzes the textual genre of the meme as an object of reading and interpretation in relation to didactic situations of learning. Like so, the reader's position must be directed critically and analytically in relation to the text and to the social and linguistic world with the aim of constructing and (re) elaborating the senses. The theoretical framework will count with the contribution of: Freire (2011), Benveniste (2014), Chartier (1999), Soares (2004), Bakhtin (2011), Adam \& Heidmann (2011), Marchuschi 2000), Schneuwly \& Dolz (2004), Bawarshi \& Reiff, (2013), Kleiman (2005), Barbosa \& Rovai (2012). At first, we will relate reflective questions about the compositional, linguistic, discursive and social dimensions of the so-called discursive textual genres, in order to demarcate the need for appropriation of these material organisms of language as objects and also as objectives of a didactic-pedagogical practice in the Portuguese language. In a second moment, for the sake of elucidation of the meme genre itself, we will present examples taken from the internet since this is the medium in which memes circulate daily, countless social networks. It is under the eyes of meme's many readers that interactive manipulation occurs in the most diverse forms. In conclusion, we understand that the reading of the meme genre operationalizes critical interpretations of the text and of the world permitting textual-discursive preconstruction of retakes.
\end{abstract}

Keywords: reading, discursive textual genres, meme(s), teaching. 


\section{Localizando a leitura}

"A leitura do mundo precede a leitura da palavra, daí que a posterior leitura desta não possa prescindir da continuidade da leitura daquele" (FREIRE, 2011, p. 19) é um enunciado emblemático do ponto de vista da alfabetização e do letramento. Todavia, precisamos estar atentos às mudanças tecnológicas que afetam não apenas a maneira de nos relacionarmos em sociedade, como também ao modo de efetuarmos a prática de leitura. Ler, assim como escrever, requer um conjunto de habilidades extraordinárias; isso se considerarmos um tipo de tradicionalidade sobre a leitura cujo alvo é a modalidade escrita da língua. Ora, lê-se muito mais do que a palavra, lê-se o mundo, como bem pontuou o mestre Paulo Freire, por meio da disposição de seus objetos, de seus sujeitos e da relação desses com aqueles funcionando simultaneamente no seio social.

Aqui entra em cena a língua como organizadora de sentidos e, sobretudo, responsável por descrevê-los e analisá-los (BENVENISTE, 2014), de maneira a tocarmos a instância do discurso onde os (efeitos de) sentido(s) estão ancorados nas múltiplas produções comunicacionais, culturais, tecnológicas, entre outras. Lê-se, desse ponto de vista, o discurso, base a partir da qual os sentidos partem, circulam e retornam, estruturados por uma ordem do discurso, refletindo, em alguma medida, uma ordem de organização social. A leitura, compreendida de um outro modo, muito ao gosto conservador, como procedimento mecânico de decodificação da língua escrita, e apenas isso, recorre a uma série de problemas ainda pouco enfrentados pela educação brasileira, em todos os níveis, porquanto lhe desvincula de uma leitura do mundo através do discurso. Uma concepção de leitura tradicional é um dos muitos entraves que precisamos 
enfrentar, pois está ligada exclusivamente a mais problemas sociais e ao apagamento destes do que a um complexo ato de interpretação dos sentidos circulantes.

Em síntese: as condições sociais de acesso à leitura, em nossa sociedade capitalista, são diferenciadas: discriminam-se as camadas populares pelo reforço de sua concepção pragmática da leitura, a que se atribui apenas um "valor de produtividade", enquanto, para as classes dominantes, ler é proposta de lazer e prazer, de enriquecimento cultural e ampliação de horizontes; supervaloriza-se um discurso escrito que legitima a ideologia das classes dominantes, expropriando as classes dominadas de seu próprio discurso; sonega-se às camadas populares o acesso à produção escrita, facilitando-o, porém, às classes favorecidas. Fica, assim, evidente a força determinante que tem a situação extra leitura - a estrutura social como sua divisão do trabalho e consequente divisão de classes sobre a leitura: na verdade, as relações de produção, de distribuição e de consumo da leitura como bem cultural repetem as condições discriminativas de produção, distribuição e consumo dos bens materiais (SOARES, 2004, p. 25; aspas da autora).

Acompanhando, pois, esse descompasso, e como atestam alguns dados de nossa realidade educativa, ainda há uma distância indesejada entre o que se ensina (e o modo como se ensina) na academia e o que se aplica nas salas de aula. O descompasso, assim, é apenas uma das contradições que compõem nossa conjuntura educacional, marcado historicamente pela ausência de políticas públicas consequentes e coerentes. Portanto, há um longo caminho pela frente, sem esquecer o olhar atento e preocupado sobre a postura e a formação docente, embasadas numa prática reflexiva que nos leve a perceber, como alertam Moura \& Martins (2012, p. 89): “a preeminente necessidade de a escola mudar o foco atual: deixar de considerar o ato de ler como atividade mecânica e de responsabilidade individual, para assumir a leitura como uma atividade em que alunos e professores sejam sujeitos ativos e colaborativos". 
Por essa razão, além de discutir (com toda a comunidade escolar) políticas de incremento à leitura, evitando que sejam impostas por quem, muitas vezes, nunca esteve numa sala de aula no papel docente, é preciso e, acima de tudo, urgente encarar seriamente a educação como prioridade maior. O que vai representar direcionamentos orientados por pesquisas capazes de reorganizar a prática e conduzir suas consequências, sanando dificuldades. Isso começará pelo diálogo entre professores e estudantes, nas esferas acadêmica e escolar, sempre marcado pela ânsia de refletir sobre a realidade e pensar mudanças para ela, refazendo o já existente e descobrindo novas alternativas.

A aprendizagem da leitura é uma tarefa cognitiva que se inicia muito antes de irmos à escola e se repercute por toda a vida: para que obtenhamos sucesso na empreitada, é fundamental, desde sempre, um incentivo por parte da família, pois, como se sabe, é mais fácil que surjam novos leitores em contextos onde se lê. Ao chegar à escola, então, ainda que façamos parte de um convívio familiar onde a leitura é atividade frequente, precisamos encontrar um ambiente propício ao alargamento dessa prática. No caso daqueles que, em casa, jamais tiveram acesso a livros ou viram seus familiares lendo algum deles, o desafio é maior e caberá à escola realizar as primeiras apresentações entre a leitura e o potencial leitor. O problema, muitas vezes, é quando isso não acontece a contento, ou se, quando ocorre, os responsáveis o fazem de modo equivocado.

A pesquisadora espanhola Teresa Colomer (2007) alerta-nos para os perigos de uma possível educação leitora contraproducente, a qual arrefecerá o gosto pela leitura, literária ou não, em vez de potencializar as competências do leitor em formação e estimulá-lo a seguir na longa e estimulante viagem de conhecimento e sabedoria que é a leitura. Segundo a autora, isso acontece quando, não raramente, "a escola dedica grandes esforços para falar de livros e autores que, simplesmente, não fazem parte do 
mundo dos alunos. A barreira existente, então, é prévia e as possibilidades de êxito são bastante escassas" (COLOMER, 2007, p. 64).

Por essas e outras razões, o fato é que ensinar a ler é um dos maiores desafios para a escola. Porque, para muito além da decodificação (apenas uma das etapas do processamento de leitura), o ato de ler compreende uma dinâmica sociocognitiva $e$ cultural capaz de transcender os limites fluidos entre o próprio leitor e o mundo que o cerca.

Destarte, uma localização da leitura sob bases relativamente mais democráticas tenciona compreender, entre outras coisas, o funcionamento da difusão de sentidos amplamente distribuídos atualmente em nossa sociedade através do uso e emprego das tecnologias digitais e, desse modo, examinar e promover a leitura sob essas bases. "A grande questão é compreender como as limitações são sempre transgredidas pela invenção" (CHARTIER, 1999, p. 19), que em nosso caso refere-se à internet e a suas ferramentas de produção e de compartilhamento de sentidos - nomeadamente, em memes.

\section{Práticas de leitura e de escrita com os gêneros textuais discursivos}

A linguagem humana compreende um conjunto de práticas discursivas efetivadas nas relações sociais, que se dá, principalmente, em torno das habilidades de fala e escrita. Complexa, mutável, abrangente e difusa, a linguagem se ramifica pluralmente em inúmeras manifestações e, assim, não somente abarca as múltiplas identidades sociais que Ihe dão forma, como é por elas modificada. Todas as realizações linguísticodiscursivas materializam-se em gêneros, os quais, por sua vez, são atingidos por (e/ou 
fazem refletir) visões ideológicas, pois, como sabemos, por indicação bakhtiniana, nenhum discurso é puro.

Assim, na medida em que nos propomos a discutir sobre a caracterização genérica de memes e a necessidade de trabalho com ela, fazemos um recorte teórico que tenciona destacar as razões precípuas sobre por que nos apropriarmos dos conceitos fundamentais de gênero, com ênfase nos chamados memes da internet - essa tão frequente e cotidiana manifestação da linguagem em ambientes virtuais/cibernéticos da contemporaneidade.

Os gêneros integram um circuito histórico de várias tradições teóricas de investigação. Neste tópico, no entanto, traremos apenas um panorama sintético das teorias, contemplando, de maneira geral: a entrada e permanência da "moda" dos gêneros na academia e na escola; alguns dos principais aspectos conceituais sobre gênero; o papel dos gêneros na dinâmica escolar do ensino de língua portuguesa.

Existe, na linguística, uma dupla nomenclatura para se referir a esses arquétipos linguísticos dos quais tratamos: numa direção, inscreve-se neles o termo "textuais", enquanto, em outra, opta-se pela expressão "discursivos". Apesar das diferenças entre os rótulos, que, diga-se de passagem, aqui não serão tratadas a fundo, acreditamos que a opção por uma ou por outra não faz diferença no objetivo central pretendido com a apropriação prática dos referidos construtos linguísticos: fazer deles um relevante instrumento de exploração das competências linguísticas de ler, escrever, falar e ouvir.

Mas o que define um gênero? Na clássica comprovação de Bakhtin (2011, p. 262; grifos do autor):

Todos esses três elementos - o conteúdo temático, o estilo, a construção composicional - estão indissoluvelmente ligados no todo do enunciado e são igualmente determinados pela especificidade de um 
determinado campo da comunicação. Evidentemente, cada enunciado particular é individual, mas cada campo de utilização da língua elabora seus tipos relativamente estáveis de enunciados, os quais denominados gêneros do discurso.

A clareza da acepção explicitada pelo teórico russo é uma das mais importantes aberturas conceituais no fecundo leque de definições que se nos oferece: para Bakhtin, o gênero se define pelo conteúdo temático, pelo estilo e pela construção composicional, e no texto dedicado a essa categorização, ele justifica o conceito por meio da interligação entre esses pontos, sempre evidenciando que o gênero está, indiscutivelmente, atrelado aos fatores da variação e da estabilidade. Isto é, a própria natureza genérica do emprego da linguagem é variável, mas nunca se aparta de uma ideia primária que sempre lhe dará forma, daí porque não surpreende que Adam \& Heidmann (2011, p. 26) dialoguem abertamente com Bakhtin e reafirmem que "os gêneros são categorias prototípicas definíveis por tendências ou classes de tipicalidade, por feixes de regularidades e fenômenos de dominância".

Marcuschi (2002), ao compor uma análise esclarecedora sobre a natureza conceitual dos gêneros, assevera que, mesmo limitado, um certo número de gêneros foi desenvolvido por povos de cultura essencialmente oral, mas com o passar do tempo e em decorrência da escrita alfabética por volta do século VII a. C., eles se multiplicaram, fazendo surgir os de expressão escrita.

Tal surgimento foi apenas um pequeno sinal para a intensidade produtiva que viria - a qual, desde primários dias até o presente, faz verdadeira esta outra afirmação de Bakhtin (2011, p. 262): 
A riqueza e a diversidade dos gêneros do discurso são infinitas porque são inesgotáveis as possibilidades da multiforme atividade humana e porque em cada campo dessa atividade é integral o repertório de gêneros do discurso, que cresce e se diferencia à medida que se desenvolve e se complexifica um determinado campo.

Portanto, os gêneros dependem das práticas sociais, pois a efetiva interdependência entre ambos possibilita o aparecimento e a continuação de eventos comunicativos mediados e sustentados pelos textos. Por isso, afirma-se que gêneros são elementos maleáveis, mutáveis, passíveis de transformação continuamente, uma vez que, com a evolução tecnológica, especialmente na esfera da internet, sempre surgem práticas discursivas que dão origem a novas constituições - os chamados hipertextos ou gêneros digitais, entre outros.

Dessa forma, quanto mais se intensifica o uso das novas tecnologias nas atividades comunicativas, mais gêneros podem aparecer (e desaparecer), porém a sua natureza funcional os define mais do que qualquer outra coisa. Mesmo assim, os critérios para se determinar um gênero são variáveis e não existem regras fixas. Em algumas vezes, a forma influencia sobremaneira; em outras, prevalece a função; por fim, há momentos em que o suporte sobressai.

Em cada campo existem e são empregados gêneros que correspondem às condições específicas de dado campo; é a esses gêneros que correspondem determinados estilos. Uma determinada função (científica, técnica, publicística, oficial, cotidiana) e determinadas condições de comunicação discursiva, específicas de cada campo, geram determinados gêneros, isto é, determinados tipos de enunciados estilísticos, temáticos e composicionais relativamente estáveis (BAKHTIN, 2011, p. 266). 
A partir do momento em que analisamos as teorias de gênero para garantir uma postura cuidadosa em nossas análises, atentamos à necessidade de tratar o tema sem os reducionismos que (de modo similar ao que acontece com o par oralidade/escrita) nele estariam implicados. Mais especificamente, dizemos que, para além do aspecto formal, cabe no trabalho com os gêneros o conhecimento dos elementos não formais (apontados na declaração acima) que possibilitam a sua consecução e permanência. Isto é, as esferas sociais são, de modo substancial, grandes responsáveis pela determinação dos gêneros, pois não seria possível falar deles "sem pensar na esfera de atividades em que se constituem e atuam, aí implicadas as condições de produção, de circulação e de recepção" (BRAIT, 2000, p. 20).

Dessa forma, esse direcionamento interpretativo fez germinar as tradições retórica e sociológica de gênero que - como tão providencialmente Bawarshi \& Reiff (2013) registram em seu trabalho - concentram-se, sobretudo, na relação que se estabelece entre a existência mesma dos gêneros e a capacitação permitida por esses aos usuários da língua para a realização retórica e linguística de ações simbólicas, as quais, por sua vez, conferem aos atores da interação a inegável possibilidade de cumprirem papéis e relações sociais que moldam realidades sociais. Além disso, como continuam a indicar os autores, "os estudos retóricos de gênero se concentram no modo como os gêneros, através de seu uso, mantêm e ajudam dinamicamente a reproduzir práticas e realidades sociais, além de revelar suas tensões internas" (BAWARSHI; REIFF, 2013, p. 81).

Assim, no interior dessa dinâmica teórica, e também de acordo com os autores supracitados, afigura-se pertinente a contribuição da linguista americana Carolyn R. Miller, que, por seu turno, enriquece o debate com a defesa de "gênero como prática social". 
Para Miller, portanto, os gêneros devem ser definidos não só em termos da fusão de traços substanciais e formais que corporificam em situações recorrentes, mas também pelas situações sociais que ajudam a produzir. Em situações recorrentes, os gêneros mantêm motivos sociais para agir e proporcionam estratégias retóricas tipificadas para que seus usuários possam agir (Ibid., p. 96).

Nessa lógica, antes de serem tão somente ferramentas comunicativas, os gêneros inscrevem-se socialmente como modos de negociação social complexos e difusos que abarcam os participantes numa rede interativa. Esse movimento compreende ação dupla: a) favorece a realização de motivos sociais, negociados com os motivos individuais, apontando para a dinamicidade que interliga os gêneros às suas situações de uso; b) leva a "coordenar o desempenho de realidades, interações e identidades sociais" (Ibid., p. 102).

\section{A dinâmica dos gêneros na sala de aula}

Acreditamos ser de especial importância considerar a proposição teórica até aqui aventada, porque ela também contribui para as práticas interventoras em sala de aula: ou seja, é por apropriar-se corretamente de visões coerentes que o professor (ou qualquer outro profissional que tenha a linguagem como seu ofício) tem a chance de desempenhar o(s) seu(s) papel(éis) mais antenado com a realidade e a sociedade, numa postura de quem entende que a prática linguística jamais se desvincula do meio em que atuamos como cidadãos, responsáveis pela convivência diária fundada no interdiscurso dialógico.

Outra temática digna de atenção e tratada por Marcuschi (2002) se refere à noção de texto e discurso, cujos limites, apesar de tênues, não impedem definições bem 
marcadas, pois o segundo depende do primeiro para se constituir. Contudo, ambos se encontram entremeados e implicados, mas, não podemos esquecer, o discurso é a intenção, o ter o que dizer, aliado fiel do propósito comunicativo e da individualidade ideológica do produtor; enquanto o texto é a oportunidade concreta e física de materialização desse discurso e dessa intenção que integra a capacidade comunicativa dos indivíduos.

Assim, é pelo texto que damos a conhecer ao outro o nosso posicionamento discursivo acerca de tudo quanto pensamos e sentimos, o que se afina com o posicionamento de Brait (2000), para quem não existe enunciado que não se configure em gênero. Mas, diz ela, isso não se dá "de uma forma pura e simplesmente determinista". E completa, atenta ao fator dialógico entre os textos e os discursos produzidos historicamente:

Se vou me expressar em um determinado gênero, meu enunciado, meu discurso, meu texto será sempre uma resposta ao que veio antes e suscitará respostas futuras, o que estabelece a profunda diferença entre intertextualidade (diálogo entre textos) e interdiscursividade (diálogo entre discursos) (Ibid., p. 19).

A autora ainda nos apresenta um exemplo para melhor compreensão dessa diferença, quando cita a criação da Odisseia, de Homero: quando o grego deu vasão à sua potência criativa, ele não o fez do nada, do raso e do branco, mas, antes de qualquer coisa, retomou as vozes que lhe antecederam, vozes que já narravam a seu modo e tempo essa história. Assim, Homero retoma os discursos histórico e literário, outrora celebrados e construídos por seus antecessores, e os reorganiza textualmente no gênero epopeico, fundando-o, assim, no rol da literatura universal. Numa confirmação exemplar 
de que, como apontam Adam \& Heidmann (2011, p. 22), "os sistemas de gêneros e os gêneros evoluem e desaparecem com as formações sociodiscursivas às quais eles estavam associados".

Além disso, é fundamental não ignorarmos também que os enredamentos, retomadas e desdobramentos que compõem os gêneros (fazendo-os desaparecer, ganharem novas roupagens ou se transmutarem em novas construções) não são um fato observado somente na relação propriamente dita entre um texto e outro; entre um texto e um discurso, ou entre textos e discursos. Para a compreensão mais precisa dessa ideia, não se faz menos necessário, em princípio, desfazer distorções quanto às diferenças entre tipo textual e gênero textual. Marcuschi (2002) adverte para que não mais se confundam esses termos, pois: tipo textual se caracteriza por peculiaridades linguísticas (basicamente, as espécies de tipos de texto são definidas pelas seguintes ações: narrar, expor, argumentar, instruir, descrever), enquanto gênero textual é, entre outras definições, a materialização linguístico-textual-discursiva da capacidade humana de produzir textos falados, escritos, verbais e não verbais.

Desse modo, num único texto podem coexistir diferentes sequências tipológicas, articuladas pelo mecanismo da coesão, um dos elementos da textualidade. Por essa razão, é notável o quanto os gêneros se entrecruzam, fazendo surgir, dos diversos conúbios, por exemplo, situações em que um gênero se apresenta com determinada forma, mas sua finalidade surpreende o leitor, pois seria esperada por um outro gênero com forma diferente daquela - além dos casos em que alguns gêneros contêm a presença de vários tipos textuais, mesclados harmonicamente. Uma das razões para esse fato, como vimos, são as estruturas sociais e a cultura, que operam nos gêneros, direta ou indiretamente, inúmeras variações no decorrer do tempo. 
Além das considerações expostas, vale ressaltar as seguintes: na academia ou na escola, a manipulação dos gêneros orais e dos gêneros escritos e a distinção entre ambos exigem cuidado de quem trabalha com eles - por serem um poderoso e essencial instrumento de ensino e aprendizagem e também por se estabelecerem numa relação de aproximações e interdependências. Por isso, sabendo ainda que a variedade dos gêneros discursivos nos manuais didáticos ainda é insuficiente, cabe ao professor aprofundar-se no estudo dessa construção da linguagem humana, para desenvolver (com/para seus alunos) atividades fundamentadas, visando ao aprimoramento da competência discursiva. Em outras palavras, "partimos da hipótese de que é através dos gêneros que as práticas de linguagem materializam-se nas atividades dos aprendizes" (SCHNEUWLY; DOLZ, 2004, p. 63; grifos dos autores).

O empreendimento pesquisador de Schneuwly \& Dolz e colaboradores (2004), em que também nos embasamos, tornou-se, a partir de sua tradução/publicação, uma referência no estudo dos gêneros como arquétipos linguísticos e da sua transmutação em objetos/instrumentos de ensino-aprendizagem em todos os níveis da educação linguística. O gênero que, assim como a literatura, não depende da escola para se constituir autonomamente, passa, então, a escolarizar-se.

Nesse sentido, cabe ressaltar: tal como orienta a pesquisa dos autores mencionados, a decisão de levar um gênero para a sala de aula deve ser o resultado de uma discussão guiada, principalmente, pelo conhecimento de seus aspectos centrais, mas não apenas, como temos insistido, quanto às características formais, e sim numa exploração intensiva das condições de produção, contextuais e cotextuais; do papel dos interlocutores; das habilidades implicadas na leitura e na produção de cada gênero; da variação nas etapas de produção (a saber, a programação em sequências didáticas 
propostas pelos teóricos).

Assim, um dos desafios capitais demandados por essa empreitada será coordenar tais variáveis numa elaboração de atividades permeadas pelo que os referidos pesquisadores compreendem como três etapas diretamente implicadas e em constante atividade, descritas como a efetuação de três princípios no trabalho didático. São eles:

- $\quad$ princípio de legitimidade (referência aos saberes teóricos ou elaborados por especialistas);

- $\quad$ princípio de pertinência (referência às capacidades dos alunos, às finalidades e aos objetivos da escola, aos processos de ensinoaprendizagem);

- $\quad$ princípio de solidarização (tornar coerentes os saberes em função dos objetivos visados) (Ibid., p. 70).

O primeiro princípio (de legitimidade) vai exigir do profissional uma ação pesquisadora, de maneira que exercite o papel de leitor atento e interessado em saber mais detalhadamente sobre os elementos que compõem o cotidiano de seu trabalho. Isso representará interesse pessoal e profissional para realizar leituras de textos científicos e didáticos, a fim de ampliar seus conceitos e aprimorar a sua prática, pois uma ação segue na direção da outra: o educador e a educadora dedicados em aprofundar-se na sua área de atuação farão repercutir em sua práxis o conhecimento a que tem acesso por meio de sua predisposição pesquisadora. No entanto, para isso contam fatores inerentes à profissão e muitas vezes difíceis de conciliar, tais como: as próprias condições de trabalho relacionadas ao tempo do professor; as possibilidades (inclusive financeiras) de investimento intelectual; a existência de boas instituições superiores de licenciatura aliadas à atuação de profissionais com as mesmas desejáveis condições de trabalho, entre outros. 
O segundo princípio (de pertinência) visa a clarear posturas docentes que estejam norteadas por questões-chave capazes de indagar os envolvidos e possibilitar a busca por sentidos à prática: que gêneros ensinar e por quê? Na comunidade em que se situa a escola, o que se torna mais relevante no trabalho com os textos? Quais os anseios dos alunos e como articulá-los à finalidade almejada? A propósito, qual finalidade ou objetivo de fato interessa concretizar? Como se percebe facilmente, esta segunda proposição está diretamente relacionada ao desenvolvimento metodológico no produtivo laboratório que deve ser a sala de aula.

O terceiro princípio (de solidarização) completa essa tríade que nos serve de orientação para a tomada de decisões quanto aos direcionamentos que precisam se efetivar durante o percurso das atividades com os gêneros. Portanto, assim como os autores afirmam, a orquestração dos três princípios não é uma ação isolada, mas deve ser vista como uma "interação em perpétuo movimento" para que os mecanismos metodológicos, os objetivos pretendidos e as condições didático-pedagógicas estejam aliados. Diante disso, é fundamental não nos esquecermos de tratar a situação com objetividade, estabelecendo prioridades e metas, e oferecendo clareza àquilo que desejamos alcançar - os gêneros são uma construção de linguagem e, como tal, devem servir ao aprofundamento das capacidades linguísticas daqueles que os manuseiam.

Finalmente, cabe-nos registrar a consideração de Barbosa \& Rovai (2012, p. 29) quanto ao trabalho com os gêneros: trata-se da preocupação sumária em formar não especialistas em características de gênero, mas em contribuir com a formação de "leitores literários, de periódicos, de textos de divulgação científica", e igualmente de "produtores de textos que, efetivamente, tenham o que dizer, que possam contribuir 
com debates sociais, posicionar-se criticamente em relação aos fatos do mundo e às produções culturais".

\section{Memes: uma pré-construção textual-discursiva de retomadas}

O termo "meme" aparece pela primeira vez no livro O gene egoísta, publicado em 1976 pelo zoólogo britânico Richard Dawkins. Assim, ao cunhar o neologismo, o autor nos adianta que há muitos exemplos de "memes" em circulação pela sociedade:

são melodias, ideias, slogans, as modas no vestuário, as maneiras de fazer potes ou de construir arcos. Tal como os genes se propagam no pool gênico saltando de corpo para corpo através dos espermatozoides ou dos óvulos, os memes também se propagam no pool de memes saltando de cérebro para cérebro (DAWKINS, 2007, p.330, grifos do autor).

Com isso, o teórico faz recair sobre a sua exemplificação de "memes" a ideia central que Ihes dá corpo: a propriedade de transmissão, isto é, algo que pode ser replicado, ainda segundo Dawkins, por meio da imitação. Nesse sentido, é importante ressaltar que a redução "meme" nasce do termo grego "Mimeme", qual seja, algo que pode ser copiado. Memética, por sua vez, é uma palavra utilizada para se referir ao estudo formal dos "memes". O autor afirma ainda que estava em busca de um termo mais curto que se assemelhasse sonoramente a "gene" de onde se tem, em suma, que o "meme" é o "gene da cultura".

Conforme Dawkins (2007, p. 325): 
A maior parte daquilo que o homem tem de pouco usual pode ser resumida numa palavra: "cultura". A transmissão cultural é análoga à transmissão genética, no sentido de que, apesar de ser essencialmente conservadora, pode dar origem a uma forma de evolução.

Sendo assim, os memes que circulam na internet são produções linguísticas, culturais e discursivas que não se restringem a combinações de imagem e texto verbal. 0 meme, tal como vemos na definição primeira de Dawkins (2007), atravessa diferentes contextos sociais no intercâmbio das formações simbólicas de cultura e, desse modo, possibilita a apropriação e difusão desta em múltiplas estratégias de realização material e discursiva de ideias e práticas. No entanto, quando nos reportamos ao contexto midiático, especificamente ao da internet, deparamos com esses artefatos que, em geral, aparecem na forma do gênero textual discursivo denominado meme, o qual, de modo mais amplo, organiza-se pela combinação de texto verbal e imagem, ou apenas imagem, ou até mesmo imagem em movimento e, assim, mobilizando configurações as mais variadas, requer do leitor uma intepretação que relacione aspectos linguísticos, sociais, culturais, políticos e ideológicos.

Assim o meme, na condição de gênero textual discursivo, é construção que se processa pela disponibilidade de interação sociocognitiva, situada histórica e socialmente, conduzida pelos sujeitos em permanente contato. Para se efetivar, o meme necessita que os indivíduos manifestem estratégias mentais e as executem. Mas não somente isso, pois a fim de produzir sentido, é necessário que, durante o processamento e a recepção, os interlocutores mobilizem conhecimentos diversos e mesmo externos à materialidade textual (o conhecimento de mundo partilhado), responsáveis pela conjunção de fatores que se inter-relacionam durante a elaboração recíproca do texto. Nessa relação, percebese claramente que autor, texto e leitor/receptor estão imbricado na aceitação da ideia de 
que se tem um construto textual não apenas quando se tem um bloco de palavras e/ou imagens organizadas sequencialmente (na fala ou na escrita), mas no momento em que os agentes desse processo produtivo se cruzam entre si para a consecução da finalidade que se pretende alcançar.

A partir de agora, passamos às considerações exemplificadoras de memes retirados da internet, com a finalidade de comentá-los à luz das reflexões provocadas.

Figura 1 - Meme 1

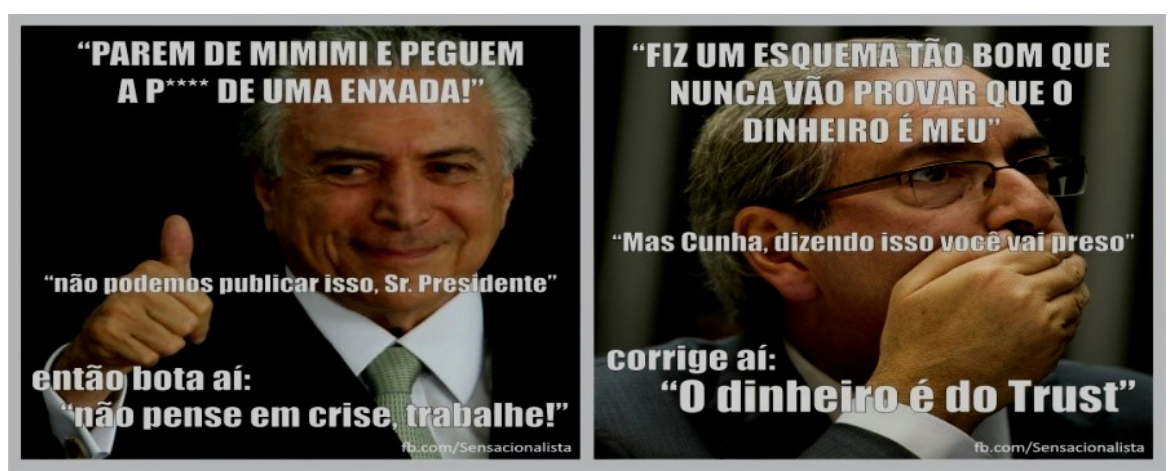

Fonte: <www.sensacionalista.com.br/2016/07/19/exclusivo-10-memes-nao-podemos-publicar-isso-so-compoliticos/>

O meme acima traduz de maneira didática, tal como podemos observar no princípio de solidarização de (SCHNEUWLY; DOLZ, 2004), uma das muitas ocorrências na qual o imaginário social é acionado para "produzir" ou recobrar uma interpretação predeterminada. Portanto, as condições de produção social da leitura desse meme já estão tomadas como evidentes, o que de certa maneira parece favorecer a universalização de uma leitura do discurso circulante em nossa sociedade. Então, por um lado, o meme subverte a leitura linearizada pela escrita e pela fala, circunscrevendo uma semiose híbrida prenhe de significado extraído de um saber popularizado/midiatizado; por outro lado, condensa um conjunto de produções textuais orais e escritas orientando - 
tanto pelo humor quanto pela sua agilidade de apreensão dos fatos do mundo - uma interpretação.

Figura 2 - Meme 2

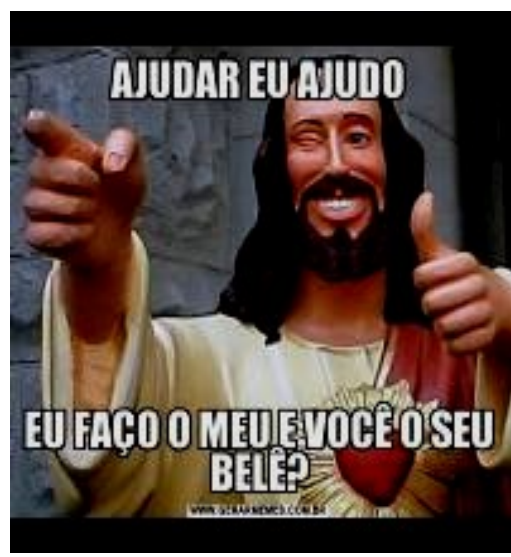

Fonte: <www.gerarmemes.com.br/criar-meme-galeria/450-jesus>

A multiplicidade temática dos memes permite avançar a concepção dos gêneros textuais desenvolvida inicialmente por Bakhtin (2011) e consolidada por teóricos como Brait (2000) e Marcuschi (2002) para sua aplicação no ensino por Schneuwly \& Dolz (2004) e Antunes (2009), entre outros, pois dialoga intimamente com as novas ferramentas tecnológicas de produção e coprodução de textos. Assim, uma atualização sociodiscursiva é realizada pelos memes, uma modalidade textual relativamente nova disso decorre uma operacionalização do gênero meme como um catalizador de saberes disseminados em outras fontes mais ou menos estáveis de criação de textos.

No meme acima, o discurso religioso é mobilizado através da figura de Jesus Cristo, para instar o interlocutor a não apenas viver das esperanças de que será ajudado, mas, sobretudo, quando fizer sua parte de um acordo tácito, a outra parte estará fazendo a que Ihe cabe. Os três princípios no trabalho didático (SCHNEUWLY; DOLZ, 2004) podem ser empregados no trabalho desse meme em sala de aula, respeitando, é claro, os saberes 
e competências implicados na série e na sequência didática na qual será utilizado para enfatizar uma forma de coparticipação. Também é possível uma leitura que faça remissão ao discurso meritocrático praticado, inclusive, pela religião e por programas de governo liberais.

Figura 3 -Meme 3

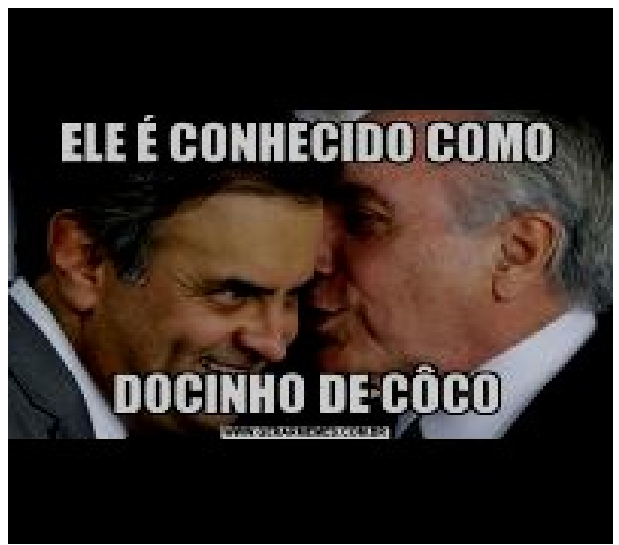

Fonte: <www.gerarmemes.com.br/meme/322323-ele-e-conhecido-como-docinho-de-coco>

O texto escrito em conjunção ao texto imagético retoma suas próprias condições de produção no interior da sociedade em que circula, interpretando, glosando, repetindo e deslocando os significados mais ou menos estabilizados nos textos tradicionalmente concebidos em tipologias. Ora, o meme parece se referir a um conjunto de fatores complexos de fabricação de textos cuja principal característica é o humor, sobretudo, o crítico. Uma vez mais, a operacionalização do gênero meme traz um vínculo estreito com a realidade discursiva imediata, facilitador didático e pedagógico da leitura e interpretação, para orientar uma cocriação relativamente participativa na difusão da préconstrução textual, haja vista o interlocutor do meme poder repassá-lo ou simplesmente excluí-lo. Desse ponto de vista é, portanto, possível e desejável um trabalho da leitura do meme como uma retomada compacta de outros textos e da relação de formulação do seu 
conteúdo com outras práticas socioculturais postas em funcionamento, tal como o cochicho, mostrado no meme acima. Quando isso é feito? Por que isso é feito? São indagações relevantes que atravessam o meme em questão e auxiliam na constituição de uma leitura e uma interpretação mais acurada desse gênero.

Figura 4-Meme 4

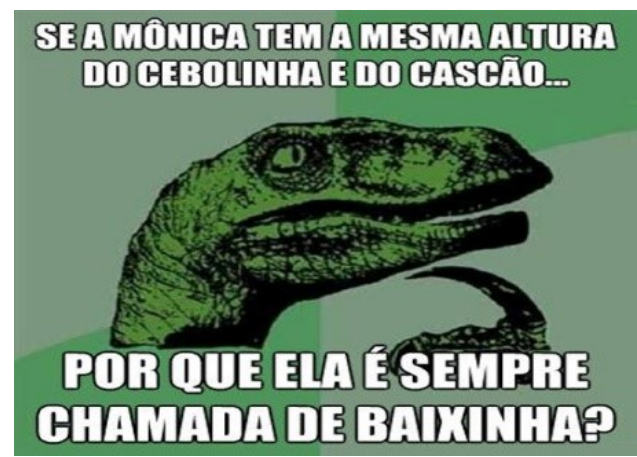

Fonte: <blog.mailee.me/usando-memes-de-internet-no-marketing/>

Os diversos questionamentos possíveis de figurarem nos memes podem ser das mais variadas ordens - portanto, é necessário perceber uma historicização na produção do gênero meme da internet. Ainda que possa haver atualizações textuais na composição dessa complexa semiose, o meme ressignifica a textualidade e seu meio de circulação social para "fundar" um percurso estruturador do sentido, o que, de per si, o torna uma forma de dialogismo altamente fluida e um acesso rico ao conjunto polifônico do interdiscurso instaurado pelo meme.

A semiotização de um dinossauro pensando numa interrogação, no mínimo inusitada, sobre por que a Mônica, que tem a mesma altura de seus colegas, é chamada de baixinha, não apenas cria o efeito de humor no interlocutor, como também the convida a refletir sobre a perspectiva de os iguais serem diferentes, deslocando, assim, a questão para outros lugares nos quais uma pré-construção textual-discursiva de 
retomadas se transforma em operacionalizador de interpretação. O funcionamento interno e externo dos gêneros gera uma tensão advinda da própria estrutura social discursivizada (BAWARSHI; REIFF, 2013).

Figura 5 - Meme 5

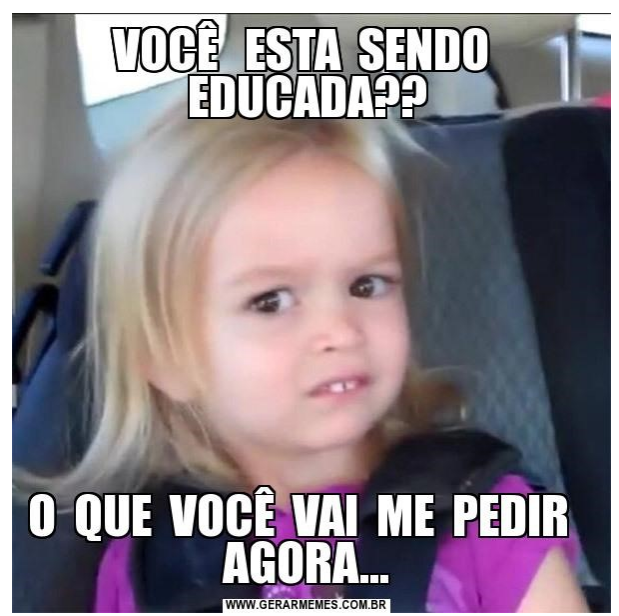

Fonte: <www.gerarmemes.com.br/meme/320124-voce-esta-sendo-educada-o-que-voce-vai-me-p>

Imagens que significam segundo sua relação contextual com a escrita não seriam uma das filiações materiais do letramento (KLEIMAN, 2005)? É fundamental percebermos que a multiplicidade dos gêneros textuais discursivos ganhou maior densidade com o advento da internet e de sua disponibilidade em aparelhos cujas funções na atualidade são totalizantes no tocante à leitura, à produção e à interpretação de textos, sobretudo, multimodais. Cabe-nos lembrar que textos híbridos não são incomuns, ao contrário, são bastante difundidos e justamente por isso o meme se Ihes aproxima, ao mesmo tempo em que deles se distancia por sua circulação, (co)produtividade, alta variação, imediaticidade sociocultural e por sua pré-construção textual-discursiva de retomadas, se transformando em operacionalizador de interpretação. Em outros termos, é possível afirmar que o meme dificilmente abre margens para inúmeras interpretações, porquanto 
sua própria interpretação está encapsulada em seu processo de construção textualdiscursivo que dialoga com suas condições mais ou menos imediatas de produção.

Em vista disso, não há novidade nos dizeres do meme acima, segundo o qual alguém está sendo educado por conveniência; contudo, há inovação no modo como essa produção enunciativa é atualizada por um meme. Ora, ao ensino da leitura, da escrita e de seus usos multimodalizados na sociedade contemporânea, institui-se a tarefa de estudar as novas formas de socialização instantânea de conhecimentos pré-construídos nos discursos circulantes, sendo uma dessas formas os memes da internet.

\section{Considerações: o meme da internet na ampliação do trabalho com gêneros textuais discursivos no ensino}

Se os memes não entrarem no processo de ensino e de aprendizagem pela via de acesso dos gêneros textuais discursivos (BAKHTIN, 2011), entrarão por uma outra via, um tanto mais perigosa: a via dos excluídos. A vida dos textos, independentemente de serem multimodais, reflete e refrata a complexidade da linguagem circulante na sociedade e, em última instância, reflete e refrata a complexidade humana. Desse ponto de vista, estudar os gêneros emergentes, sobretudo no ensino básico, requer um conjunto de procedimentos e de cuidados, tais como os descritos em Schneuwly \& Dolz (2004), para se propiciar um letramento suficientemente crítico e também capaz de mobilizar as novas tecnologias produtoras de textos densos cujo diálogo com tantos outros é demasiadamente sensível.

Não se trata, em absoluto, de uma simples aderência ao novo e moderno; antes, trata-se de uma observação de como o novo ressignifica o já existente, transformando- 
Ihe em mais possibilidades de exame do rico funcionamento da linguagem. Diante disso, ressoa a indagação de quais gêneros são os mais empregados no cotidiano e quais suas motivações sociodiscursivas para tanto, que fundamenta uma das necessidades de se estudar, se analisar e se cotejar as produções enunciativas dos memes. A partir dessa possibilidade de investigar um novo tipo de semiose é possível, então, termos no interior do gênero meme um tipo de "instabilidade", ainda que não tão evidente, com relação ao conteúdo composicional, pois esse é, sem qualquer tipo de dúvida, profundamente variado.

A leitura do meme da internet como operacionalizador de interpretação perfaz uma pré-construção textual-discursiva de retomadas condensadas de outros textos que desenha um horizonte no qual um projeto de universalização da leitura parece se aproximar a passos lentos. No universo tecnológico de cocriação dos memes, a leitura, então, adquire uma importante significação, isto é, ressignificar para engendrar sentido. Portanto, há plena razão em se dizer, tal como Freire (2011), que as leituras do mundo e da palavra estão imbricadas em interface e continuidade, por intermédio das quais se formam leitoras e leitores proficientes e críticos dos objetos que os circundam.

\section{Referências}

ADAM, Jean-Michel; HEIDMANN, Ute. O texto literário: por uma abordagem interdisciplinar. Tradução João Gomes da Silva Neto. São Paulo: Cortez, 2011.

ANTUNES, Irandé. Língua, texto e ensino: outra escola possível. São Paulo: Parábola Editorial, 2009. 
BAKHTIN, Mikhail. Estética da criação verbal. Tradução Paulo Bezerra. 6. ed. São Paulo: WMF Martins Fontes, 2011.

BARBOSA, Jacqueline P.; ROVAI, Célia F. Gêneros do discurso na escola: rediscutindo princípios e práticas. São Paulo: FTD, 2012.

BAWARSHI, Anis S.; REIFF, Mary Jo. Gênero: história, teoria, pesquisa, ensino. Tradução Benedito Gomes Bezerra. São Paulo: Parábola, 2013.

BENVENISTE, Émile. Últimas aulas no Collège de France (1968 e 1969). Tradução Daniel Costa da Silva et al. São Paulo: Editora Unesp, 2014.

BRAIT, Beth. PCNs, gêneros e ensino de língua: faces discursivas da textualidade. In: ROJO, Roxane (org.). A prática de linguagem em sala de aula: praticando os PCNs. Campinas, SP: Mercado de Letras, 2000.

CHARTIER, Roger. A aventura do livro: do leitor ao navegador. Tradução Reginaldo de Moraes. São Paulo: Editora Unesp, 1999.

COLOMER, Teresa. Andar entre livros: a leitura literária na escola. Tradução Laura Sandroni. São Paulo: Global, 2007.

DAWKINS, Richard. O gene egoísta. Tradução Rejane Rubino. São Paulo: Companhia das Letras, 2007.

FREIRE, Paulo. A importância do ato de ler. 51. ed. São Paulo: Cortez, 2011.

KLEIMAN, Ângela B. Preciso "ensinar" o letramento? Não basta ensinar a ler e a escrever? Campinas, SP: Cefiel/IEL/Unicamp, 2005.

MARCUSCHI, Luiz Antônio. Gêneros textuais: definição e funcionalidade. In: DIONISIO, A. P.; MACHADO, A. R.; BEZERRA, M. A. (org.). Gêneros textuais \& ensino. 2. ed. Rio de Janeiro: Lucerna, 2002.

MOURA, Ana A. V. de; MARTINS, Luzineth R. A mediação da leitura: do projeto à sala de aula. In: BORTONI-RICARDO, Stella Maris et al (orgs.). Leitura e mediação pedagógica. São Paulo: Parábola Editorial, 2012.

SOARES, Magda. As condições sociais da leitura: uma reflexão em contraponto. In: ZILBERMAN, R.; SILVA, E. T. (orgs.). Leitura: perspectivas interdisciplinares. 5. ed. São Paulo: Editora Ática, 2004.

SCHNEUWLY, Bernard; DOLZ, Joaquim. Os gêneros escolares: das práticas de linguagem aos objetos de ensino. In: SCHNEUWLY, B.; DOLZ, J. et al. Gêneros orais e escritos na 
escola. Tradução e organização Roxane Rojo e Glaís Sales Cordeiro. Campinas, SP:

Mercado de Letras, 2004.

Recebido em 17 de outubro de 2018.

Aceite em 25 de novembro de 2018. 